\title{
The Impact of External Debt on Nigerian Economic Growth (1990 - 2009)
}

\author{
Emori, Enya Gabriel \\ Department of Banking \& FinanceUniversity of Calabar \\ Calabar, Nigeria
}

\begin{abstract}
This study examined the Impact of External Debt on Nigerian Economic Growth (1990-2009). In order to give the study a direction, two null research hypotheses were formulated to determine the effect of external debt on investment, GDP, exchange rate and inflation. The research design used for this study was the ex-post facto research design. The econometric model employed was co-integration and error correction model to evaluate the inherent relationship between external debts and economic growth in Nigeria. The result revealed that, the impact of external debt has a positive effect on the growth of Nigerian economy. And conclude that, the severity of external debt within the period is reflected in the country's inability to meet the debt service obligations particularly scheduled debt service in relation to its foreign currency earnings. It was recommended that, the federal government should initiate the use of more superior methods to negotiate for fixed interest payment and amortization schemes.
\end{abstract}

\section{INTRODUCTION}

Like many other countries of the world, Nigeria has accumulated a large amount of external debt. Ordinarily, external borrowing ought to accelerate economic growth especially when domestic financial resources are inadequate and need to be supplemented with funds from foreign countries. Economists also believe that reasonable levels of borrowing promote economic growth through factor accumulation and productivity growth. This is because the countries at the initial stages of their development usually tend to have smaller capital stocks and their investment opportunities are limited. External debt therefore provides opportunities for economic growths and developments. It is often argued that if the borrowing countries channel the borrowed funds into productive investments and they enjoy macroeconomic stability, they will be able not only to accelerate their economic growth but also to settle their debt obligations comfortably.

Nigerian's external debt crisis was one of the critical factors which brought about the Structural Adjustment Programme (SAP) introduced in 1986 to revamp the Nigerian economy and put it on a sustainable path of recovery. The meaning of this statement is that if only the high level of external debt service payments could be reduced, Nigeria would be in a position to finance a larger volume of domestic investment which is critical for the promotion of growth and development. But more often than not, a debtor has limited opportunities to advantageously manage debt crisis. Yet Nigeria's outstanding external debt was less than \$1.0 billion in 1977. But by 1988 total external debt stock exploded to about $\$ 26.0$ billion at a time when the total value of exports from which the debt could be serviced had declined by more than half in real terms. Such large external stock with the related debt service commitments 
has hampered economic growth and development by putting a ceiling on imports which are critical for domestic production activities.

The question that needs to be answered is whether the large debt burden in Africa is one of the factors contributing to the weak economic performance and the uneven pace of economic reform in these countries, particularly in Nigeria. In attempt to answer this question two competing hypotheses: the 'debt overhang hypothesis' and the 'liquidity constraint hypothesis have been proposed. The debt overhang theory however assumes that the debtor country shares only partially in any increase in output and exports because a fraction of that increase will be used to service the external debt. The theory implies that debt reduction will lead to increased investment and repayment capacity and, as a result, the portion of the debt outstanding becomes more likely to be repaid. When this effect is strong, the debtor is said to be on the 'wrong side' of the debt Laffer curve (Were, 2001). The debt Laffer curve refers to the relationship between the amount of debt repayment and the size of debt. However, the idea of debt Laffer curve also implies that there is a limit at which debt accumulation stimulates growth (Elbadawi 1996). In reference to an aid Laffer curve, Lensink and White (1999) argue that there is a threshold at which more aid is detrimental to growth.

The liquidity constraint is captured as a 'crowding out' effect, by which the requirement to service debt reduces funds available for investment and growth. A reduction in the current debt service should, therefore, lead to an increase in current investment for any given level of future indebtedness (Cohen 1993). Other channels through which the need to service a large amount of external obligations can affect economic performance include lack of access to international financial markets and the effects of the stock of debt on the general level of uncertainty in the economy (Claessens, 1996).

However, Nigeria has made significant efforts at reducing her debt overhang as part of effort at restoring internal and external balance to the economy. While management efforts have provided some relief, the debt burden is still unbearable and unacceptable.

\section{Research hypotheses}

In order to have a framework for the study and also to answer the research questions above, the following hypotheses were formulated:

- Ho: External debt has no significant effect on Private and public investment in Nigeria.

- Ho: External debt has no significant effect on domestic economic growth of Nigeria.

\section{The nature and concepts of Nigeria external debt \\ LITERATURE REVIEW}

An objective and rigorous appraising of Nigeria's current and future approaches to her external debt overhang must be predicated on a sufficient knowledge of the magnitude of the debt, its structure, trends and determinants, as well as the economic implications of the huge debt burden. However, such desirable economic analysis could be hampered by deficient debt data which had been the case in Nigeria until recently. Fortunately, the establishment of the Debt Management Office (DMO) in October 2000, which streamlines and centralizes debt management functions in a single semi-autonomous and professional staffed agency has provided new opportunities for the generating of accurate debt statistics as well as its timely presentation (Akindose and Arikawe 2005).

Moreso, the different types of medium and long-term debts existing in the Nigeria debt stock give an indication as to the cause of the debt problem of this country. The major compound of 
the medium and long-term debts is the balance of payment which constitutes currents and capital accounts and the official settlement balance projects - tied loans constitute another form of medium terms loans. The need to accelerate the pace of economic development often prompts the government to contract project-tied loans from various international financing agencies like the World Bank, African Development Bank (ADB), International Financing Corporation (IFC) etc.

Lastly, loans for social-economic needs form a third compound of the medium and long-term debts also due to shortage of capital and financing resources, most times prompts the government to borrow from sources to finance her needs.

\section{The management of Nigeria external debt}

In spite of the enormity of the hardship caused by the debt burden in Nigeria, it was not given the serious attention it deserved early enough. For example, it was not until the last quarter of 2000 that it was considered imperative to have a full-fledged office (DMO) dedicated solely to managing the country's debt.

Although some measure of debt rescheduling and restructuring were carried out even as far back as 1986, these could not go far enough in depth and efficacy because of the absence of appropriate institutional framework. In particular, appropriate attention was not given to sustainability issues in the various restructuring exercises. The decisive shift in attitudinal and institutional aspects of debt management came with the inception of a democratically elected government in May 1999. President Olusegun Obasanjo made normalization of the national debt situation a top item in his government agenda (Isa, 2004:4).

By March, 2000, the government commissioned a review to develop an effective approach for managing the Nigeria debt. Following the findings and recommendations of the study, by October 2000, the Federal Government established the debt management office to take over focused responsibility for debt management functions which were hitherto carried out by several agencies. After its initial focus on auditing of the country's loan portfolio, updating and computerization of the debt database, the DMO has been actively involved in negotiations for the rescheduling of Nigerians external debts. In view of the size of the debts owed to the Paris club, Nigeria began negotiations with the club in October 2000 to alleviate its external debt service obligation. In December 2000, following a second round of negotiations, it reached agreement with the Paris club. The rescheduling agreement was structure in Houston terms as mentioned earlier. The Paris club agreed minutes provide the framework agreement under which Nigeria will negotiate separate bilateral agreements with the Paris club creditors. Negotiations have been held with the 15 Parish Club creditor countries with varying degrees of progress and gain. However while the Houston terms allow for a deferred of payments, they do not have provisions for any debt reduction. They are insufficient to address Nigeria's debt problem and may lead to an endless cycle of restructuring. This Nigeria debt overhang remains unassuaged.

\section{External debt and economic growth in Nigeria}

The external debt of Nigeria was N82.4 million, N435.2 and N488.8 million as at 1960 and 1970 respectively. During this same period the value of export were N339.4 million and N596.5 million and N885.4 million. The external debt figures increased slightly to N349.9 in 1975 when Murtala/Obansajo took over the mantle of leadership of Nigeria government. There was no significant increase in the total external debt during the first one year of the administration. 
But to summarize everything, the economy fluctuated between booms and recession. The direction of growth is not consistent. They were lack of correspondence between the objective of government as far as economic growth and the result so far achieved.

The growth rate of the GDP at $1977 / 79$ factor cost was negative for 1975, 1978, 1981, 1982, 1984 and 1986. This lends credence to the contention that recessions are inherent in the vary nature of capitalist dynamics. The growth rate base on per capital income during that period was not encouraging for the period (1970 - 1980).

\section{Government response to external debt burden}

Sustainable management of Nigeria's debt is a crucial policy objective for Nigeria and the DMO. These include: improving institutional arrangement for debt management to enhance transparency, efficiency and cost effectiveness, bringing debt stock and debt service payments down to manageable/sustainable levels through rescheduling/relief and seeking possibilities to restructure debt by taking advantage of market opportunities. Other options include reduction in levels of debt through debt conversions and opportunistic buy-backs.

The DMO has spearheaded the formulation of guideline for external borrowing by indicating the broad parameters for appropriate level, terms and purpose of borrowing that could be contracted as well as identifying the priority sectors. It also ensures and stipulates general criteria for approvals for these borrowing as well as servicing arrangement for the loans.

The DMO has achieved the following;

$\circ$ Loan portfolio auditing, updating and computerization of the debt database.

- Negotiating debt rescheduling with the Paris club and the subsequent $\$ 18$ billion debt relief package.

$\circ$ Taking over completely of the external debt management functions and commencement of the process of taking over of domestic debt management functions.

- Providing effective inputs into macroeconomic policy analysis and formulation.

- Concerted outreach efforts through involvement, engagement, consultation and effective communication with all stakeholders.

\section{METHODOLOGY}

The research design employed was ex-post facto research design. The sources of data available for this project study were the secondary sources. The secondary sources of data for this project included the following: textbooks, magazines, newspapers, CBN bulletins and Annual Reports, CBN Journals, Articles, publications from Federal Office Of Statistics (FOS) and Debt Management Office (DMO), periodicals, abstracts etc. There was no primary data like questionnaire used in this thesis.

In order to guide this study an econometric model adopted was adopted based on Elbadawi, Ndulu, and Ndungu (1996) model in (Were, 2001). The model for this study was explained in the External Debt - Growth Rate model and the External Debt - Investment models.

The functional form of the growth model is expresses as follows:

RGDP = f (EXTGDP, EXTGDPt-1, DSR, PRINV, REXCH, INF, PUBINV, RGDPt-1)

PRIV = $\mathrm{f}($ EXTGDP, EXTGDPt-1, DSR, RGDP, REXCH, INF, PUBINV,

RGDPt-1) 
The model for the regression analysis is presented as follows

LogRGDP $=\alpha 0+\alpha 1$ LogEXTGDP $+\alpha 2$ LogEXTGDPt $-1+\alpha 3$ LogDSR $+\alpha 4$ LogPRINV,$+\alpha 5$ LnREXCH

$+\alpha 6$ LnINF $+\alpha 7$ LogPUBINV $+\alpha 8$ LogRGDPt- $1+$ ECT $\ldots$ (3)

LogPRINV $=\alpha 0+\alpha 1$ LogEXTGDP $+\alpha 2$ LogEXTGDPt $-1+\alpha 3 \operatorname{LogDSR}+\alpha 4$ LogRGDP,$+\alpha 5 \operatorname{LnREXCH}$

$+\alpha 6$ LnINF $+\alpha 7$ LogPUBINV $+\alpha 8$ LogRGDPt $1+$ ECT $\ldots$ (4)

Where:

RGDP $=$ real GDP growth rate

EXTGDP $\quad=$ stock of external debt to GDP ratio $(-)$

EXTGDPt-1 = stock of external debt to GDP ratio lagged by one period (reflect debt accumulation) (-)

PINV = private investment as a ratio of GDP (captures the accelerator principle) $(+)$

INF $\quad=\quad$ rate of inflation (reflects macro-economic stability) $(-$ or + )

REXCH = movements in real exchange rate (reflects incredibility of policies) (-)

PUBINV = Public investment as a ratio of GDP (+)

RGDP $(-1) \quad=\quad$ real per capita income (GDP per capita, constant 1995 \$U.S.) lagged one period, measured in natural logs and $\alpha 1,-\alpha 8$ are the parameter estimate

A0 represent the constant term, ECT also represent the Error Correction Term.

\section{Data analysis}

\section{DATA ANALYSIS AND DISCUSSION OF FINDINGS}

\section{Result of the external debt-economic growth model}

The regression result for the external debt ratio and economic growth model is presented below.

$\operatorname{LogRGDP}=5.248358-0.286941 \log E X T G D P+0.318387 \log E X T G D P_{t-1}+0.021797 \log D S R-$ $0.002690 \operatorname{LogPRINV},+0.798890 \mathrm{LnREXCH}-0.002504 \operatorname{LnINF}-0.150668 P U B I N V+$ $0.952850 \operatorname{LogRGDP} P_{t-1}-0.176641 \mathrm{ECM}$

$\mathrm{R}^{2}=0.99$, Adj $\mathrm{R}^{2}=0.99, \mathrm{DW}=2.52, \mathrm{~F}-\mathrm{Stat}=371.8529$, Akaike info criterion $=-1.445705$

The empirical evidence showed that there is a negative short-run relationship between economic growth and the present level of external debt in Nigeria. In addition, there exists a negative short-run relationship between the one lag level of external debt service payment and economic growth. The result indicates that within the short run, a 100 percent increase in External debt will reduce economic development by 28.6 percent in the current year, because short term capital is not use for investment. From this result it becomes clear that external debt is inimical to economic development. The implication of this result is that the accumulation of the external debt puts pressure on economic growth as external debt repayment and servicing reduces the foreign exchange earnings of the country. This is even more evident when a relational analysis is made between external debt ratio and debt servicing ratio. The result revealed that debt servicing ratio lagged one period reduces economic development by 20 percent. The fiscal burden of debt servicing has been observed as extremely inimical to economic development in Nigeria and has been further observed as an important reason for the failure of structural adjustment programmes to restore economic growth in so many of them (Isa, 2004). This result further revealed that in attempt to reduce the burden of the mounting huge external debt, Nigeria government frequently diverts resources to take care of pressing debt service obligations instead of allocating the resources to the development of infrastructures that would have improve the well being of the citizenry. However, the coefficient of past debt accumulation (LOGEXTGDPt-1) relates positively to 
economic growth, thus contradicting the prescription of the debt overhang hypothesis in Nigeria.

The result significantly revealed that external debt reduces the impact of public investment on economic development. The result shows that as external increases by 100 percent, public investment hitherto reduces by 15 percent in the current period. It becomes clear that external debt crowds out public investment. Funds which have been directed at public investment are diverted to reducing the burden of external debts. This outcome is expected and revealed some evidence in support of the debt overhang hypothesis. Although current public investment reduces economic growth, unexpectedly, past public investment (LOGPUBINV (-1)) was found to have a positive impact on economic growth.

Current inflation rate deters economic growth while past inflation rate (INFt-1) stimulates economic growth.

The lagged Error Correction Term (ECTt-1) was included in the model to capture the long-run dynamics between the co-integrating series. The result revealed that the Error Correcting Term (ECM) is correctly signed (negative) and statistically significant. The coefficient indicates a speed of adjustment of 17 per cent from actual growth in the previous year to equilibrium rate of economic growth. The relatively low speed of adjustment implies that all errors/deviations are not corrected within one year and most of the time the economy is operating out of equilibrium.

\section{Result of the investment-external debt model}

The result of the investment-external debt model is presented below.

LOGPRINV $=\quad-4.629455-0.274061$ LOGEXTGDP -0.164151 LOGEXTGDPt $-1+$
0.273228LOGRGDP + +0.355977 LOGDSR +
0.003216 INF -0.167316 LOGREXCH

$\mathrm{R}^{2}=0.75$, Adj $\mathrm{R}^{2}=0.637, \mathrm{DW}=1.36, \mathrm{~F}-\mathrm{Stat}=16.58$, Akaike info criterion $=0.5509$

The result of the investment-external debt model revealed that the model had a very good fit of 75 percent. The F-statistics of though low, but was significant at 5 percent level. The Durbin Watson statistic did not reveal any autocorrelation.

The result revealed that external debt ratio both in the current and lagged period, though not significant in the model, but turned out with the expected negative sign. This result reveals that external debt reduces investment by 27 percent in the current period and by 16 percent in the lagged period. Thus, external debt has been discovered to crowed private investment in Nigeria. The estimated coefficient of past debt accumulation (LOGEXTGDPt-l) negatively affect public investment. This outcome is expected and revealed some evidence in support of the debt overhang hypothesis. However, that support is not robust in the model. On the other hand, debt service ratio (LOGDSR) is positively related to investment and statistically significant at $5 \%$ level, thus contradicting the prescription of crowding out hypothesis in Nigeria. The sign of this variable to investment is an aberration.

However, Isa (2004) related this aberration to the fact that Crude oil dominates the country export; and since a significant proportion of the debt service is linearly related to oil exploration through the joint venture operation, and given that oil export and investment/economic growth is highly correlated, then the outcome is not surprising. The 
more debt obligations, the oil companies and the Nigerian National Petroleum Corporation (NNPC) settled the more credit worthy the sector becomes, hence the more vibrant the sector and the economy.

The result further revealed that investment increases economic development by 27 percent in the current period and by 32 percent in the previous period. Although, this impact was not much, it would be understood that the poor contribution of investment to economic development could be attributed to the persistent fluctuation in the exchange rate. Remarkably, real exchange rate (LOGREXCH) is found to reduce investment by 16 percent in the current period and by 21 percent in the lagged period. High exchange rate increases the cost of importation of raw materials and machineries necessary for industrial production. An overwhelming problem facing private investment in Nigeria is the level of decay in infrastructure associated with poor and inoperative business environment. This situation hampers service delivery by key institutions designed to mitigate the living condition of vulnerable groups. By cutting down expenditure on social and economic infrastructure, the government appears to have also constrained private sector investment and growth through lost externalities.

It was also revealed from the result that past inflation (INFt-1) discourages current private investment. This could imply that economic agents expect the previous year's high level of inflation rate to persist in the current period, thus discouraging current private investment. Thus investor face tougher situation in the current period if past inflation rate are not brought under control.

\section{DISCUSSION OF FINDINGS}

The study was set forth to investigate the relationship between Nigeria's external debt and its impact on economic development in Nigeria. From the hypothesis tested, the study had concluded that external debt has a huge and adverse impact on economic development in Nigeria. From the result previously analyzed, the study had observed that a 10 percent increase in external debt has the propensity to reduce economic development by 28 percent. The explanation proffered for this adverse condition is that debt poses as a deduction on future output, discouraging productive investment plans of the private sector and adjustment efforts on the part of governments. In a sense, foreign debt acts like a tax when the debt situation is such that given any improvement in the economic performance of the indebted country, part of gains goes to higher debt repayments; that is, creditors receive part of the fruits of increased production or exports by the debtor country. Nigeria frequently diverts resources that would have been used for infrastructural development and improved service conditions to take care of external debt servicing. The empirical result of external debt and debt service payment and economic growth is in agreement with the findings of Iyoha (1999), Essien and Onwuoduokit (1998), which confirms that large stocks of external debt tend to lower the rate of economic growth in the Nigerian economy.

Savvides (1992) aptly asserted that if a debtor country is unable to pay its external debt, debt payments become linked to the country's economic performance. The country benefits only partially from an increase in output or its exports because a fraction of the increase from exports proceeds is used to service the debt. Such accruals are credited to the creditor countries. However, arguments have been presented that external debt does not in its totality reduce economic performance, but rather countries that experience a reduction in economic performance do so because of their inability to service their debt as at when due. Such 
unwarranted delay in remitting debt payment attracts interest payment which often results to debt overhang situation.

Further explanations on the poor economic performance of Nigeria due to her huge external debt situation could be related to the country's inability to service debt on time which makes it harder for the country to get aid at concessional rates with less conditionalities from the donor agencies. This situation not only reduces the overall level of foreign direct investment that enters the country but also forces the country to rely heavily on domestic borrowings, which at the same time further reduces the economic balance of the nation.

\section{Summary of Findings}

\section{SUMMARY, CONCLUSION AND RECOMMENDATIONS}

In the previous chapter, we had presented and interpreted the result of the estimated parameters of the models. In this chapter, the study discussed the various results in line with the result of the hypothesis previously tested in chapter four. The study also presented a sustained policy analysis that should be undertaken by the Government of Nigeria.

The study was carried out using Ordinary Least Square (OLS), on time series data covering the period 1970-2009, bearing in mind recent developments on co-integration and error correction models (ECMD). Tests of the order of integration of the variables and the ECMD were conducted using Augmented Dickey-Fuller (ADF) tests and the result shows that several of the variable are stationary after differencing once (integrated of order one) except for Inflation which was stationary (integrated of order zero) at $5 \%$ level of significance.

After observing that the variables in the equations had no unit roots, the study proceeded to conduct the co-integration analysis using the Johansen Co-integration technique. The maximum eigenvalue test and the likelihood ratio indicated the existence of two co-integrating equations.

- This result further emphasized that there will be a long run relationship between the variables in the equation. Summarily, the Error Correcting Term (ECT) in the growth equation came out with the expected negative sign and a magnitude of 17 percent. This result further indicate in cases of deviation between the long run from the short run, the degree and speed of correction will be 17 percent. The relatively low speed of adjustment implies that all errors/deviations are not corrected within one year and most of the time the economy is operating out of equilibrium. Thus the system is likely to experience a slow equilibrium condition during periods of deviation.

$\circ$ The Granger Causality test also revealed that there exist a unidirectional relationship that runs from external debt ration to debt servicing ratio. This result amplified the relationship that usually external debt poses huge debt servicing burden on every country including Nigeria. The study also observed a unidirectional causal relationship that runs from public investment to debt servicing ratio. This result implies that funds that are accruable from government public investments are majorly directed at servicing public debt in Nigeria.

o The study while attempting to study the external debt servicing burden of the country relied on the preferred external debt indicator, the external debt-to-export ration. The result of this study observed that external debt servicing lagged one period reduces the level of economic development of the country. Thus the result of the study is consistent 
with the theories of debt overhang and liquidity constraints and therefore concludes that external debt hampers economic growth through the channel of public investment. In the public investment equation, the estimated coefficients of current and past debt accumulation (LOGEXTGDP and LOGEXTGDPt-l) negatively affect public investment. This outcome which is however expected revealed some evidence in support of the debt overhang hypothesis. However, that support is not robust in the model. On the other hand, debt service ratio (LOGSDSR) is positively related to investment and statistically significant at $5 \%$ level, thus contradicting the prescription of crowding out hypothesis in Nigeria. This result confirms the opinion as was observed by Isa (2004).

- Considering the result of the investment - external debt service ratio in the current period, the result does not support the debt overhang hypothesis. This aberration could be explained that while neglecting the negative export ability of the country to service her debt through the export resources, the country further relies on the external net financing to run the economy. This net external financing often gauge the effect of lean externally generated revenue accruable to the country.

\section{CONCLUSION}

From the result of the analysis, the study concluded that GDP growth rate is positively related to public investment through accelerator mechanism and this supports the a priori expectation of economic theory that the rate of growth of GDP should be positively related to investment.

Debt serving does not crowed out public investment; therefore the study does not support the debt overhang hypothesis as is often posited by other researchers. In sum, the paper concludes that encouraging alternative financing through foreign direct investment, portfolio investment, and non-guarantee private debt is the feasible long-run solution to the Nigeria, external debt problems. Nigeria still has a chance of overcoming her external debt problems by cultivating the right policies.

The simultaneous attainment of sustainable economic growth and reduced external debts would appear difficult at the moment and could remain elusive if aggressive measures are not undertaken. The government of Nigeria could play an important role in stimulating the economy if the resources obtained from the debt relief initiatives are targeted at productive public investments with the resultant crowding-in effects on private investment, and social spending for the poor.

In as much as external debt burden is a reality in Nigeria, it is also true that the country cannot achieve its goal of becoming an industrialized nation by the year 2020 without external financial assistance. However, over reliance on external finance should be discouraged since this aggravates the problem of lean external sources of funds. However, availability of external finance should be consistent with a policy framework that is credibly maintained (fiscal stance, exchange rate policy, interest rate policy, pricing policy, etc.). It is expected that the government should provide enabling environment that would promote private investment in the country by creating credible political will that could spur investors' confidence for both local and foreign investment.

\section{Recommendations}

Although Nigeria adopted the following strategies to ameliorate external debt by placing embargoes to new loans; limit on debt service payment (maximum of 30\% of export earnings) debt restricting through refinancing, rescheduling, buyback, issuance of collateral bonds etc. 
but against the background of the major findings, other approaches which can help debt payment to be sustainable in Nigeria as well as enhance economic growth and development include:

$\circ$ The use of more superior methods to negotiate for fixed interest payment and varying amortization schemes. Nigeria should seek multi-year rescheduling rather than year by year basis.

- African debtor nations should come together form a union and collectively bargaining with their creditor's association rather than facing such associations of London and Paris clubs individually.

- External finance should be used only for projects of highest priority. This is so because it is huge external debt that threw us into the series of economic problem in the first instance.

- The implementation must stipulate period long enough (10 years or more) before dividends can be repatriated for investment to mature.

\section{References}

Adepuju, A. (2007). Keynote address at seminar of management of Nigerian external debt in Olukoshi A. (ed) Nigerian external debt crisis, its management. Lagos: Malthouse Press Ltd.

Ademola, S. (2005). Trade and external debt issues. Published by Unilag Press, Lagos, 67 - 71.

Adeyemi, P. (2010). Beyond structural adjustment: a policy framework. Nigeria Economic and Financial Review 4 (2) $26-30$.

Andrews, C. (1991). Recent developments in econometric methods and application to the demand for mine in Kenya, African Economic Research Consortium, Special Paper 15, Nairobi Kenya.

Anyanwu, T. (1993). Impact of Nigerian external debt on the economy. Journal of Monetary Economy, 2 (1) 21 - 6.

Anyanwu, T. (1997). Drops of oil in a sea of poverty the case of a new debt deal for Nigeria. Retrieved March 5, 2007 from www.jubilee.plus.org.

Anyanwu, T. (2000). An analysis of external debt and capital flight in severely indebted low income countries in Sub-Saharan Africa. International Monetary Fund Working Paper, 97 (68), 12 - 15.

Asika, E. (2004) Research methodology made easy; published byHudson Nigeria, Owerri, Imo state.

Baker, J. (1985). Statement before the annual meeting of the IMF and World Bank, Seoul, South Korea $8^{\text {th }}$ October.

Bauer, P. (1984). A proposal for third world debt management, speech delivered in Zurich June, 29 Carmichael, Jeffrey, (1989), the debt crisis, where do we stand seven years? World Bank Research Observer Washington DC. Vol. 4 No. 2 July 1989.

Bauer P. (1991). The development frontier: Essays in applied economics. Hemel Hempstead Publishers.

Beenstock, M. (1984). The world economy in transition. London: George Allen and Unwin.

Bradley, N, (1989). A proposal for third world debt: Speech delivered in Zurich, June 29th 1986.

Brandford, S. and Kucinski (1988). The debt squads: the US, the Banks and Latin America. London: Zed.

Central Bank of Nigeria (2000). Poverty profile for Nigeria. Statistical Bulletin 8, 36 - 45.

Claessens S. (1996). Debt overhang, debt reduction and investment: The case of Philippians. International Monetary Fund Working Paper 90 (77), 1 - 7.

Classens, S. \& David, N. (1993). Estimates of capital flight. World Bank Policy Research Working Paper Series, 1186, $45-48$

Cline, W. (1984). International debt: Systematic risk and policy response. Washington DC. 
Cohen, D. (1993). Large external debt and slow domestic growth: A theoretical analysis. Journal of Economic Dynamics Control 19, 1141 - 1163.

Corbridge, S. (1993). Debt and development Blackwell - Oxford UK. Emudu printing UK.

Daiz, A. (1984). Latin American Debt: I don't think we are in Kansas anymore. Brookings Paper on Economic Activity 2, $335-89$.

Deepak, L. (1983). The poverty of development economics. London. Institute of Economic Affairs.

Dikpo, O. (2005). Daily sun newspaper. Politics of Nigeria's debt relief, October 31, 2005, 21.

Edward, A.D. (1988). The debt crisis and development: A comparison of major competing theories. Geoforum 19, 3 -28 .

Elbadawi, I. (1996). Debt overhang and economic growth in the 1980s: Evidence from the Sub-Saharan: Canadian Journal of Development Studies, 20(2)307-318.

Elbadawi I, Ndulu C and Ndungu 0. (1996). Growth and foreign debt; the Tanzania experience. Journal of Monetary Economics, 14(3)50-56.

Engle, G (1987). Mathematics analysis in economics and business: USA Malhouse Press, Chicago.

Essien, O. and Onwuoduokit C. (1998). Adjustment policy of debt crisis and capital formation in developing countries: The Indian Economic Journal, 35(50) 68-78

Fosu, A. (1996) Debt Overhang and Economic Growth in sub Saharan. Canadian Journal of Development Studies, 20 (2)307-318.

George, A. (1989). The impact of Nigeria's external debt on the economy. Nigeria economic and financial review 5 (2) $36-40$.

Griffith J. and Sunkel (1986). Debt and development crisis in Latin America: The end of an Illusion Oxford Clarendin Press, Grimwade N. (1989). International Trade: New patterns of trade.

Isa A. (2004). The impact of external debt on economic growth and investment. Published in Nigeria.

Iyoha, C. (1999). Debt conversion scheme in Nigeria. Villars publication, Owerri Nigeria.

Johansen, M. (1991). International economics: Theory policy and applications. Canadian Wusen Publications.

Kayode, 0. (2006). The effect of Nigeria external debt on the development of Nigeria Economy. Konstant Publications Ltd. Owerri, Nigeria.

Kruger, A. O. (1974). The political economy of the rent seeking society. American Economic Review 64, 291 - 303.

Kruger, A. (1985). The US as a debtor country: Causes prospects and implications business review. Federal Reserve Bank of Philadelphia.

Lensink, B. White, C. (1999). From crisis to sustainable Development. Publication of World Bank 19 (12) 26 - 35.

Mackinnon, B. (1996). Policy stimulation with models of external debt and economic growth in sub Saharan Africa countries. Nigerian Economic and Financial Review, 2(1) 51-59.

Newey, C. and West, B. (1994). The Africa debt crisis. Journal of Monetary Economics, 32(3)36-39

Nzotta, S. (2004). Money, banking and finance: Theory and practice. Published by Hudson Nigeria publishers No. 24 Royce Road, Owerri Imo State.

Oluwale, A. (2007). Daily independent: Eight years of mixed fortunes. May 23, 2007:12 (2) 12-14

Oluwatayo,D.W. and Olasupo, (2001). Issues in money finance and economic management. Publication of Unilag Press. University of Lagos

Roddick J. (1988). The dance of millions Latin American and the debt crisis. London: Latin America Bureau.

Sachs J. (1989). Developing country debt and the world economy. Chicago, University of Chicago Press/NBER. 
Sach, J. (1988). Effective debt reduction. (In Shrat Hussain and Ishan Diwan) dealing with the debt crisis, Washington DC.

Sach, J. (1998a). Genesis of Nigeria debt problems, problems prospects for debt conversion. Paper presented at workshop on the operations of debt conversion Lagos 3 - 14 June 1988.

Savvides, P. (1992). External debt and economic growth. International Monetary Fund Working Paper, 69(5)43-52.

Sjaasled, L. (1983). International Debt Quagmire: To whom do we owe it? The World Economy, 6:305-24.

Soludo, C. and Ngozi, I. (2004). The debt trap in Nigeria. Bullion a Publication of the Central Bank of Nigeria, 24(2) 39-43.

Telegram E. (1992). External debt crisis and economic growth in Nigeria. Nigerian Journal of Economics and Development Matters, 2 (1) 85 - 97

Vaubel R. (1983). The moral Hazard of IMF Lending. The World Economy, 6:291 - 303.

Walton, A. (1989). Debt-equity conversion as an instrument of structural adjustment in Nigeria, paper presented at the two-day national seminar on the management of Nigerian's external debt organized by HIIC Lagos February 1988

Were, L. (2001). Management of external reserves: Bullion a Publication of the Central Bank of Nigeria, 19 (12)26 35 .

World Bank (1989) the change role export agencies. Bullion, a Publication of World Bank, 24 (2)39-40. 